\title{
Analysis of Air Pollution in the Urban Center of Four Cities Sicilian
}

\author{
G. Cannistraro ${ }^{1 *}$, M. Cannistraro ${ }^{2}$, A. Cannistraro ${ }^{3}$ and A. Galvagno ${ }^{1}$, \\ ${ }^{1}$ Department of Engineering of Messina, University of Messina, Contrada di Dio, 98166 Messina, \\ Italy \\ ${ }^{2}$ P. D. University of Messina \\ ${ }^{3}$ Freelancer Engineer
}

Email: gcannistraro@unime.it

\begin{abstract}
The process of urbanization in this new millennium is characterized by the fact that more than three quarters of Europe's population is concentrated in urban areas, thus it becomes essential the issue of how to reconcile the development of our cities with the respect and protection of the environment. Polluting vehicle emissions constitute a major contribution to the deterioration of urban air quality and represent a potential risk to public health of citizens. The qualitative improvement of processes of production it is to be considered in the near future, a priority for urban pollution reduction and for improving the quality of life of our cities. This paper shows the air pollution analysis of the urban center of four Sicilian city, and the concentrations of the critical pollutants ( $\left.\mathrm{PM}_{10}, \mathrm{NO}_{2}, \mathrm{SO}, \mathrm{O}_{3}, \mathrm{CO}, \mathrm{C}_{6} \mathrm{H}_{6}, \mathrm{NH}_{3}, \mathrm{NMVOC}\right)$. Linear regressions were performed to represent the relationships between the main pollutants; they were analyzed also the differences between the concentrations of pollutants, and their progress over the years.
\end{abstract}

Keywords: Environmental pollution, Pollution levels, Linear regression, Air quality index, Statistical analysis, $\mathrm{PM}_{10}, \mathrm{NO}_{2}, \mathrm{SO}, \mathrm{O}_{3}, \mathrm{CO}, \mathrm{C}_{6} \mathrm{H}_{6}, \mathrm{NH}_{3}, \mathrm{COVNM}$.

\section{INTRODUCTION}

The process of urbanization in this new millennium is characterized by the fact that more than three quarters of Europe's population is concentrated in urban areas, thus it becomes essential the issue of how to reconcile the development of our cities with the respect and protection of the environment.

With the persistence of the crisis that weighs on our country and on much of the Western world, you begin to glimpse a turnaround in the development of the City, they must implement development policies geared towards greater sustainability, essential for growth.

The qualitative improvement of urban development processes is to be considered central in view of a better quality environment and in the use of exhaustible resources.

In this context, the ISPRA provides at the city managers, data that can be used for future choices of local government and in the evaluation of what has been done.

These data provide insight for improving the environmental indicators, such: as the decrease in the concentration of pollutants in the air, due to the spread of green vehicles, the increasing separate waste collection and the use of renewable energies.

The Italian Cities with the "Covenant of Mayors"have shown particular attention to the initiatives to combat climate change and to the protection and the quality of the environment, more than 2,100 Italian municipalities are involved in the drafting and implementation of plans to reduce of the climate altering emissions.

These are projects aimed at upgrading the buildings, at the energy saving, at energy production from renewable sources, at integrated waste management.

These measures to improve air quality, at the urban mobility policies sustainable can represent at local level an motor in the development and the revival of investment and employment $[1,13]$.

\section{THE REGULATORY FRAMEWORK}

During 2010 the regulatory framework for air quality has changed substantially, the previous legislation, articulated in a framework law (DL 351/99) and decrees (which provided the measurement mode, information on the number and placement of monitoring stations, limits and reference values for different pollutants), has been replaced by a single standard, the Legislative Decree of 13 August 2010, 155 "Implementation of Directive 2008/50/EC on the quality of "ambient air and cleaner air for Europe."

The decree transposing the European Directive 2008/50 /EC, provides new tools that have the goal of reduced effectively the air pollution $[14,15]$. 
In addition to providing a benchmark methodology for the characterization of the zones (the zoning) defines the reference values which allow an assessment of air quality, on an annual basis, in relation to the concentration of various pollutants.

In particular are defined:

- Limit Value (LV): level to be attained within a given period, and not to be exceeded thereafter;

- Objective Value: Level to be achieved, wherever possible, by a given date;

- Critic Level: level above which, risks may occur and damage to ecosystems and at the vegetation, not for humans;

- Tolerance Limit: Percentage of the limit value by which it is accepted to go beyond the LV;

- Alarm Threshold: level beyond which there is a risk to human health, the achievement of which requires it to ensure adequate and timely information;

- Information Threshold: level beyond which there is a risk to human health for certain sensitive groups, the achievement of which requires it to ensure adequate and timely information;

- Objective at Long-term: Level to be achieved in the long run through determined measures;

- Average Exposure indicator: Level to be verified on the basis of selected national background stations, which reflects the average exposure of the population;

- Obligation of exposure at the concentration: Level to be reached by a given date;

- National exposure reduction target: reduction average exposure percentage compared to a base year, to be achieved by a given date.

\section{EMISSIONS AND AIR QUALITY}

Air pollution is an environmental emergency that affects particularly the large urban areas, where the highest human settlement of the territory and where consequently the levels of pollutants are high and the high is the exposure for the population. The Italian municipal administrations to obtain comparable results, generated by a same methodology, they have proposed as a primary objective for the feedback of pollutant emissions, the production and standardized presentation of the main emission sources in cities.

With this criterion they can be assessed in the Italian urban areas, for each type of pollutant, the main sources of emission into the atmosphere.

As it regards the local reality is preferable to refer at local monitoring, undoubtedly more specific and detailed, but difficult to compare between them why often made with different methodologies.

The starting point for a municipal level estimates is made by the provincial disaggregation of values national of emissions, conducted every five years by ISPRA, taking as the basic hypothesis that the urban area is coincident with the municipal area.

This approximation allows you to estimate emissions related to all sources contained in the municipal limits, or ignore the others outside the city limits.

It is important, that the approach used is uniform so as to have results comparable to identify the greatest sector of the impact emissive to be able to program synergistic actions and effective.

The current legislation in Italy and Europe, stipulates that individuals responsible for the management of air quality are required to draw up plans for air quality, to bring at fixed standards the air pollutants in the zone where they have been overcome, and to ensure its respect.

This is achieved through the adoption of measures to limit and reduced the emissions into the atmosphere, and for obtained the non-critical values of the ambient air quality, in the land areas that have higher value standards.

For several decades, the scientific community is also studying the effects of air pollution also on the wealth of historical and artistic interest.

The interaction between the airborne substances and the cultural heritage is a phenomenon that usually damages the work of art, both visually and from a structural point of view. This phenomenon in our cities, can be monitored by performing studies of blackening and erosion/corrosion of the materials constituting cultural property (marble, glass, copper).

\subsection{Suspended particulate, $\mathrm{PM}_{10}$}

Most of the suspended particulate, PM10 emitted in cities, comes from sources distributed on the territory and employees on the one hand by the urban planning and on the other by the habits of citizens. For particulate material from anthropogenic sources, the sector most emissive is that of home heating followed by road transport.

The presence of pollutants can be caused by the issue of civil and residential installations [16, 25].

Emissions from home heating, are subject of investigation by the national and international scientific community. In some urban areas, the presence of certain industrial activities have hired a predominant role, despite, in recent years, the abatement technologies have enabled significant reductions.

The contribution of the sector to the heating of primary particulate emissions is approximately $37 \%$, while that due to road transport is estimated at $31 \%$.

The emissions from heating are concentrated mainly in winter, where, for details weather conditions, a large numbers of the overruns of the limits for particulate concentrations of the air, prescribed by law occur.

\subsection{The nitrogen oxides, $\mathrm{NO}_{\mathrm{x}}$}

The nitrogen oxides $\left(\mathrm{NO}_{\mathrm{x}}\right)$ are a family of gases that are produced during the high-temperature combustion.

The air comburent in the combustion processes, is constituted by $80 \%$ from nitrogen.

The main emission sources are represented by the exhaust gases of motor vehicles and domestic heating, and from large plants in which there are combustion processes.

The second sector by emissivity, turns out to be the home heating. The presence of an industrial pole may become predominant in specific situations, in each case the trend of the emission in recent years are decreasing.

The NOx contribute to the formation of secondary particulates inorganic and ozone $\left(\mathrm{O}_{3}\right)$ tropospheric (at ground level).

Among the chemical species designated by the term $\mathrm{NO}_{\mathrm{x}}$, is nitrogen dioxide $\left(\mathrm{NO}_{2}\right)$, which is associated with adverse health effects: high concentrations cause inflammation of the airways and function reduced lung.

The $\mathrm{NO}_{\mathrm{x}}$, and $\mathrm{SO}_{2}$, contribute to acid deposition, but also, and if in excessive amount, they can produce eutrophication of soil and water. 


\subsection{NMVOC, volatile organic compounds, non-methane}

The Volatile Organic Compounds (VOCs) are a set of chemicals, which are in the liquid or vapor form, they are characterized by the ability to easily evaporate at room temperature.

These compounds are emitted from a large number of sources, the application of paints, the road transport, the dry cleaning and other uses of solvents.

The NMVOCs are secondary precursors of $\mathrm{PM}_{10}$ and of ozone tropospheric.

The compounds that fall into this category are more than 300, among the best known: benzene, the chloroform and formaldehyde (known carcinogenic to humans), and ethanol. In the cities the main source of emissions is the use of solvents although in some cities have equaled the values of emissions from road transport.

\subsection{Sulphur oxides, $\mathrm{SO}_{\mathrm{x}}$}

They are essentially consist of sulfur dioxide $\left(\mathrm{SO}_{2}\right)$, a gas colorless, irritating, very soluble in water and a pungent smell, and in small part by sulfur trioxide $\left(\mathrm{SO}_{3}\right)$, the sulfur oxides are mainly emitted from the use of fuels and chemical industry.

The health effects can range from simple irritation to the respiratory tract and eye, and in the case of an acute exposure, to phenomena of bronchial constriction for prolonged exposure to even quantities not high; oxides of sulfur are also precursors of secondary $\mathrm{PM}_{10}$.

The progress made over the last 20 years in the regulatory and in technology environment with the consequent reduction in the sulfur content in fuels and the use in the production of electricity of fuels without sulfur content, have resulted in a considerable reduction of domestic emissions and, consequently, at the level of urban areas. During rainy days, the fallout of pollutants produced from sulfur oxides is a major component for the formation of "acid rain", which can represent significant impacts on aquatic ecosystems in rivers and lakes and damage to forests.

\subsection{Carbon monoxide, $\mathrm{CO}$}

The Carbon monoxide $\mathrm{CO}$, is an incomplete combustion product of organic fuels (coal, oil, wood, fuels) and is a gas particularly poisonous and insidious, odorless, colorless and tasteless.

The carbon monoxide is toxic because, by binding to iron atoms of hemoglobin in the blood, it form a much more stable complex, capable of releasing, in the mode more difficult, oxygen to tissues.

Also for the carbon monoxide, the road transport, constitutes the principal source emission for the main Italian cities and its contribution is above $50 \%$.

The second source of $\mathrm{CO}$ emissions in the cities is the heating, with contributions generally lower but still comparable to those of road transport.

\subsection{Benzene, $\mathrm{C}_{6} \mathrm{H}_{6}$}

The benzene is produced by incomplete combustion of carbon-rich compounds, it is produced naturally in volcanoes or in a forest fires, but also by smoke cigarette and by exhaust gases from motor vehicles.

For benzene, road transport is the main emission source, almost all of the emissions are generally attributable to products linked to the fuel cycle: refining, fuel distribution and above all vehicular traffic.

The second source of emission is usually made up of the activities related to the use of solvents, with contributions that can exceed $30 \%$ of city emissions.

Even for benzene, the existence of particular sector industries, are can provide make a dominant contribution of these activities.

The policies undertaken at various levels over the years have led to sharp reductions in benzene emissions of $-42 \%$ and $-78 \%$, compared to 2000 .

\subsection{Ammonia, $\mathrm{NH}_{3}$}

The ammonia, $\mathrm{NH}_{3}$ is a nitrogen compound, is presented as a colorless, toxic, with characteristic smell pungent. At the national level, almost all emissions is in agriculture and in the management animal waste.

In urban areas, the total weight of these activities is lower, it also emerge other sources.

The second source of ammonia in urban areas it is represented by the road transport; in particular the contribution is due to catalyzed vehicles and the possibility that the catalytic processes used to reduce $\mathrm{NO}_{\mathrm{x}}$ emissions, can generate ammonia emissions.

\section{ANALYSIS OF THE AIR QUALITY IN THE FOUR SICILIAN CITIES}

The ISPRA in 2000-2010 has performed research about air quality in the national territory [15].

In this paper, an analysis of air quality in some cities of the Sicilian territory is been carried out, in particular in the cities of Palermo, Messina, Catania and Syracuse.

The data used are referred at the years 2000, 2010 and 2012, and they consist to values of $\mathrm{PM}_{10}$ particles, nitrogen oxides ( $\mathrm{NO}$ and $\left.\mathrm{NO}_{2}\right)$, benzene $\left(\mathrm{C}_{6} \mathrm{H}_{6}\right)$, of ground-level ozone $(\mathrm{O})$, carbon monoxide $(\mathrm{CO})$, compounds organic volatile, non-methane (NMVOC), oxides of sulfur (SO) and ammonia $\left(\mathrm{NH}_{3}\right)$.

To understand how it changed air quality over the years they are analyzed the trends of time series of concentration data of the pollutants main: $\mathrm{PM}_{10}, \mathrm{NO}_{2}$ and $\mathrm{O}_{3}$. In these four Sicilian cities were analyzed the main pollutants in atmosphere, and the measured values were compared with the limits set by the legislation

- SUSPENDED PARTICULATE, PM10 and PM2.5: For the purpose of protecting human health, the Legislative Decree no.155/2010 establishes for $\mathrm{PM}_{10}$ and $\mathrm{PM}_{2.5}$., respectively the values limits annual of 40 and 25 micrograms $/ \mathrm{m}$, and a limits value daily for $\mathrm{PM}_{10}$, of 50 $\mu \mathrm{g} / \mathrm{m}^{3}$ not to be exceeded more than 35 times in a year. The daily limit value, is the more stringent than the annual value, and is the most frequently exceeded limit.

- NITROGEN DIOXIDE, $\mathbf{N O}_{2}$ :The Legislative Decree $155 / 2010$, with regard to polluted emissions of nitrogen dioxide, for the protection of human health establishes the hourly limit value of $200 \mu \mathrm{g} / \mathrm{m}^{3}$, and for the hourly average concentration, not must exceeded more than 18 times in a year, an annual limit value $40 \mathrm{~g} / \mathrm{m}$.

-OZONE, O $\mathbf{3}_{3}$ : The Legislative Decree no. 155/2010 as a long term goal, establishes for the protection of human health, a value ozone of $120 \mu \mathrm{g} / \mathrm{m}^{3}$ (under this concentration value of $\mathrm{O}_{3}$, are possible, on human health and on the environment, of the effects harmful); an information threshold of $180 \mathrm{~g} / \mathrm{m}^{3}$ (a 
level beyond which there is a risk to human health, for from brief exposure, for particularly sensitive sections of the population and at which the measures provided for by rules to be adopted and regulations), and a alert threshold level of 240 $\mu \mathrm{g} / \mathrm{m}^{3}$.
- BENZENE, C6 $\mathbf{H}_{6}$ : The Legislative Decree 155/2010, defines for benzene for the purpose of protecting human health an annual limit value of $5.0 \mu \mathrm{g} / \mathrm{m}^{3}$.

The Tab.1 below shows, for each pollutant, the limit values and reference the DL 155/2010.

Table 1. Limit values and reference set by Decree $155 / 2010$ for the various pollutants

\begin{tabular}{|c|c|c|c|c|c|c|}
\hline $\begin{array}{l}\text { Polluting } \\
\text { type }\end{array}$ & $\begin{array}{l}\text { Annual } \\
\text { limit }\end{array}$ & $\begin{array}{l}\text { Daily } \\
\text { Limit }\end{array}$ & $\begin{array}{l}\text { Hourly } \\
\text { limit }\end{array}$ & $\begin{array}{l}\text { Protection } \\
\text { threshold }\end{array}$ & $\begin{array}{c}\text { Threshold } \\
\text { Information }\end{array}$ & $\begin{array}{l}\text { Threshold } \\
\text { alaım }\end{array}$ \\
\hline PM10 & $40 \mu \mathrm{g} / \mathrm{m}^{3}$ & $\begin{array}{c}50 \mu \mathrm{g} / \mathrm{m}^{3} \\
<35 \text { times a year }\end{array}$ & & & & \\
\hline PM2,5 & $25 \mu \mathrm{g} / \mathrm{m}^{3}$ & & & & & \\
\hline $\mathrm{NO}_{2}$ & $40 \mu \mathrm{g} / \mathrm{m}^{3}$ & & $\begin{array}{c}200 \mu \mathrm{g} / \mathrm{m}^{3} \\
<18 \text { times a year }\end{array}$ & & & \\
\hline $\mathrm{O}_{3}$ & & & & $120 \mu \mathrm{g} / \mathrm{m}^{3}$ & $180 \mu \mathrm{g} / \mathrm{m}^{3}$ & $240 \mu \mathrm{g} / \mathrm{m}^{3}$ \\
\hline $\mathrm{C}_{6} \mathrm{H}_{6}$ & $5,0 \mu \mathrm{g} / \mathrm{m}^{3}$ & & & & & \\
\hline $\mathrm{Pb}$ & 0,5 & & & & & \\
\hline $\mathrm{CO}$ & & $10 \mathrm{mg} / \mathrm{m}^{3}$ & & & & \\
\hline $\mathrm{SO}_{2}$ & & $125 \mu \mathrm{g} / \mathrm{m}^{3}$ & $350 \mu \mathrm{g} / \mathrm{m}^{3}$ & & & \\
\hline
\end{tabular}

In Fig. 1 and in Tab. 2 are shown for the years 2000 and 2010 , the values annual emissions, expressed in $\mathrm{t} /$ year, of the main pollutants. It can be seen from the graphs, that all emissions of the various pollutants in the four cities have been reduced on average by $30 \%$ and $50 \%$ with the exception of the, matter particulate PM10, which has remained constant on average; in the SO present reductions more than $70 \%$.

Table 2. Values of the annual emissions of major pollutants, expressed in t/year

\begin{tabular}{|l|c|c|c|c|c|c|c|c|}
\hline \hline \multirow{2}{*}{ Palermo } & 2000 & 633 & 8582 & 13829 & 559 & 40062 & 175 & 488 \\
\cline { 2 - 9 } & 2010 & 590 & 4337 & 8634 & 132 & 19506 & 47 & 252 \\
\hline \multirow{2}{*}{ Messina } & 2000 & 325 & 4329 & 5038 & 564 & 15347 & 65 & 272 \\
\cline { 2 - 9 } & 2010 & 314 & 2815 & 3296 & 101 & 7732 & 19 & 174 \\
\hline \multirow{2}{*}{ Syracuse } & 2000 & 201 & 1836 & 2528 & 463 & 20480 & 85 & 230 \\
\cline { 2 - 9 } & 2010 & 168 & 709 & 1536 & 83 & 9589 & 26 & 112 \\
\hline \multirow{2}{*}{ Catania } & 2000 & 404 & 4990 & 5897 & 274 & 7832 & 31 & 277 \\
\cline { 2 - 9 } & 2010 & 406 & 2196 & 3567 & 13 & 3845 & 8 & 152 \\
\hline
\end{tabular}
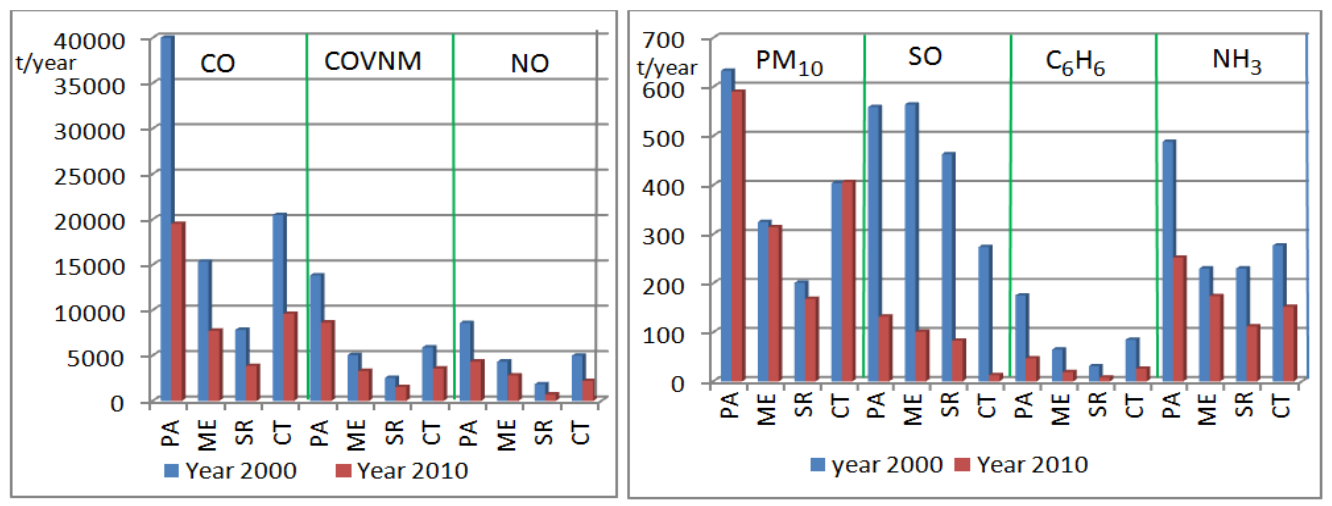

Figure 1. Values of the annual emissions of major pollutants, expressed in $t / y e a r$

- In the Fig.2 are shown respectively the minimum and maximum values emission of $\mathrm{PM}_{10}$ and $\mathrm{NO}_{2}$, values related at the years 2011 and 2012, expressed in $\mathrm{mg} / \mathrm{m}^{3}$, for in the four Sicilian cities.

- In the Fig.3 are shown the minimum and maximum values of the annual average concentration by $\mathrm{C}_{6} \mathrm{H}_{6}$.

- In the Fig. 4 are shown for the years 2010 and 2012, the minimum and maximum number of hours for which there have been $\mathrm{NO}_{2}$, concentration with values higher than 200 $\mathrm{mg} / \mathrm{m}^{3}$ (levels beyond which there is a risk to human health, and for brief exposures the measures provided for by rules and regulations should be adopted, as an hourly average).

- In the Fig. 5 are shown the correlations between the COVNM and the $\mathrm{PM}_{10}$ and $\mathrm{PM}_{10}$ and $\mathrm{NO}$, it is observed that the two straight lines of equation [1] and [2] show good correlation coefficients.

- In the Fig. 6 are shown the correlations between the $\mathrm{C}_{6} \mathrm{H}_{6}-\mathrm{PM}_{10}$, and $\mathrm{PM}_{10}-\mathrm{NH}_{3}$, it is observed that the two 
straight lines of equation [1] and [2] show good straight lines of of equations [3] and [4] have acceptable correlation coefficients but lower than the case of Fig.5.

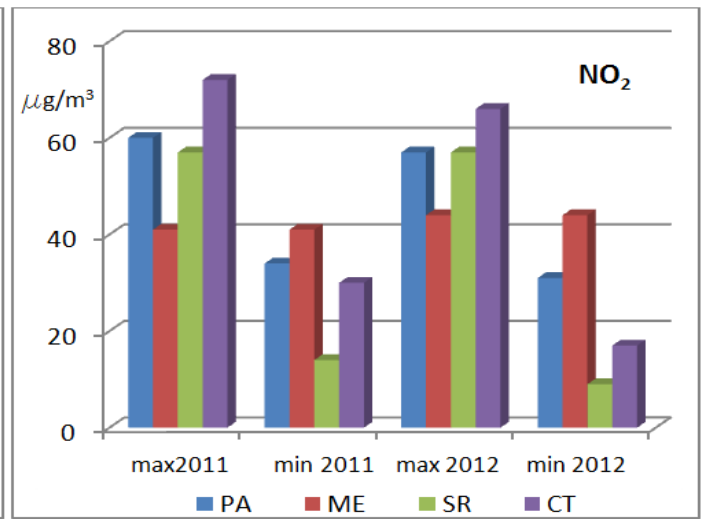

Figure 2. Max and Min values, of the annual mean concentrations of $\mathrm{PM}_{10}$ and $\mathrm{NO}_{2}$

$$
\begin{aligned}
& \mathrm{COVNM}=22,03 \mathrm{PM}_{10}-2833,6 \quad \mathrm{R}_{1}=0,913[1] \quad \mathrm{NO}=12,142 \mathrm{PM}_{10}-891,38 \quad \mathrm{R}_{2}=0,827 \quad[2] \\
& \mathrm{NH}_{3}=0,492 \mathrm{PM}_{10}+57,47 \quad \mathrm{R}_{3}=0,713 \quad[3] \quad \mathrm{C}_{6} \mathrm{H}_{6}=0,152 \mathrm{PM}_{10}-\mathbf{0 , 8 5 3} \quad \mathrm{R}_{4}=0,469 \quad[4]
\end{aligned}
$$

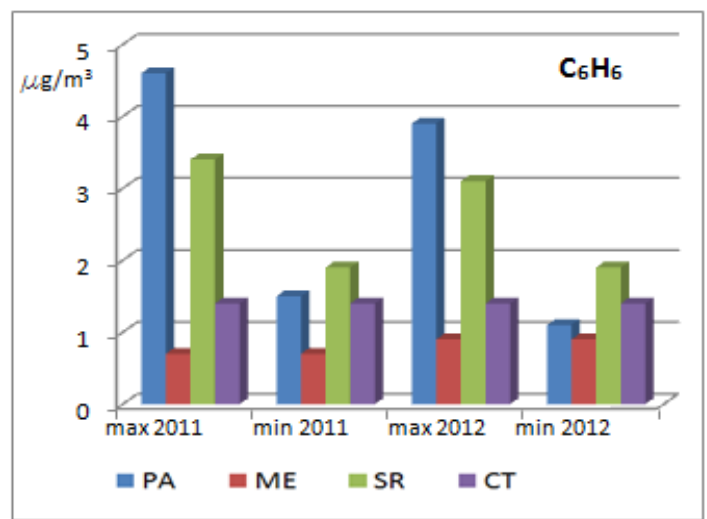

Figure 3. Max and Min values, of the annual mean concentration $\mathrm{C}_{6} \mathrm{H}_{6}$, for the four locations

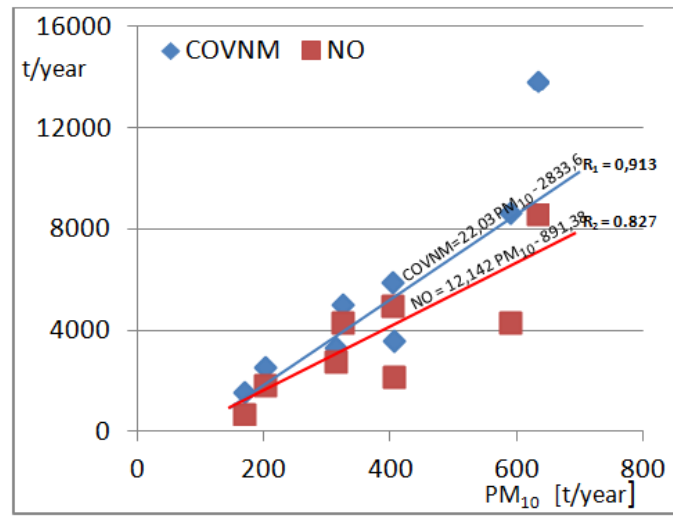

Figure 5. Correlation between $\mathrm{PM}_{10}$ and NO red curve end correlation between $\mathrm{PM}_{10}$ and COVNM blue curve

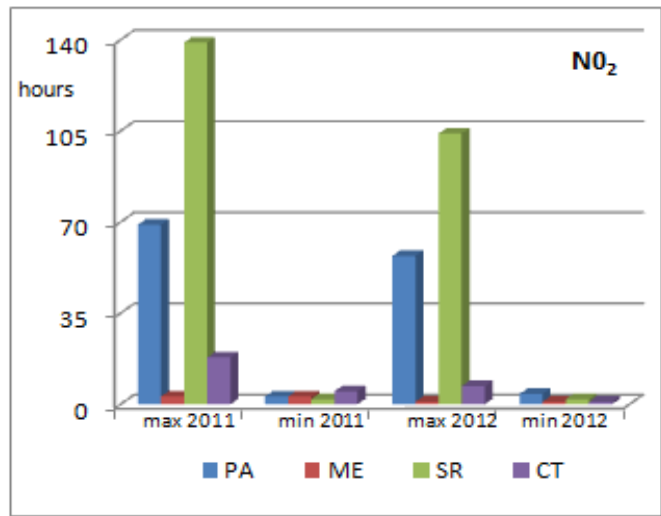

Figure 4. Number hours with $\mathrm{NO}_{2}$ concentrations greater than $200 \mathrm{mg} / \mathrm{m}^{3}$

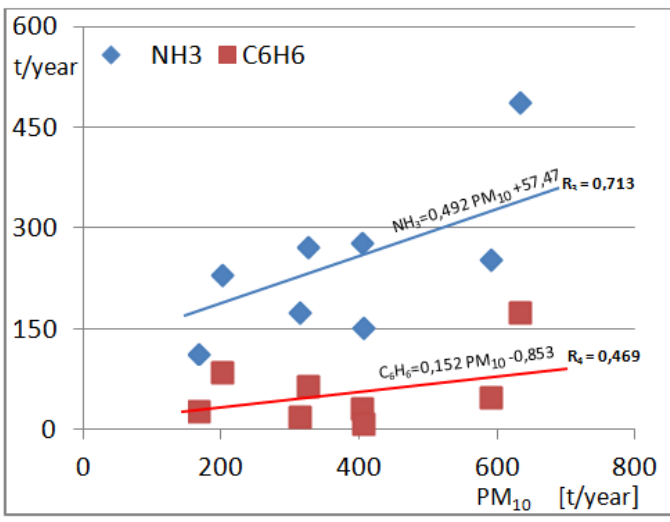

Figure 6. Correlation between $\mathrm{PM}_{10}$ and $\mathrm{C}_{6} \mathrm{H}_{6}$ red curve end correlation between $\mathrm{PM}_{10}$ and $\mathrm{NH}_{3}$ blue curve 


\section{FINAL CONSIDERATIONS}

The persons responsible for the assessment and management of air quality, ie regions and autonomous provinces, as required by Legislative Decree no. 155/2010, are required to prepare the "Air quality plan", in cases where levels in ambient air and pollutants:sulfure dioxide, nitrogen dioxide, benzene, carbon monoxide, lead and particulate matter PM10, exceeded the respective limit values or target values, established by the said decree. Main objective of the "Air quality plans"is to identify effective measures to ensure compliance with the limits within the time allowed.

The study carried out by ISPRA, reports that the daily limit value for $\mathrm{PM}_{10}$ was exceeded in the four cities of Sicily, the average levels are usually lower in the cities of Catania and Messina, the daily limit is exceeded in Palermo and Syracuse, as annual limit value. In 2011 and 2012 is showed that in all four cities, the annual limit value for benzene has respected, this reduction of benzene levels at lower values than the limit, it is very important in view of the known serious health effects associated at the exposure inhalational. The exceeding the annual limit value for $\mathrm{NO}_{2}$ is frequent and extended to most urban areas of the four Sicilian cities of the present study, in spite of the years from 2006 in 2011, there has been a widespread tendency to reduce the concentration of $\mathrm{NO}_{2}$ with a trend descending statistically significant.

Nationally VOC emissions, in the period between 2000 and 2010, they respected the limits imposed by the National Emissions Ceilings Directive. The emission trends of sulfur oxide, taking as reference the year 2000 it was generally down, mainly due to the evolution of the containment technologies in the automotive field.

\section{REFERENCES}

[1] Defense, H., "Health effects of outdoor air pollution," American Journal of Respiratory and Critical Care Medicine, pp. 477-498, 1996.

[2] Traversi, D., Degan, R., De Marco, R., Gilli, G., Pignata, C., Ponzio, M., Rava, M., Sessarego, F., Villani, S. and Bono, R., "Mutagenic properties of PM2.5 air pollution in the Padana Plain (IT) before and in the course of XX Winter Olympic Games of 'Torino 2006',' Envir. International, pp. 966-970, 2008.

[3] Al-Hurban, A. E. and Al-Ostad, A. N., "Textural characteristics of dust fallout and potential effect on public health in Kuwait City and suburbs," pp. 169. $181,2010$.

[4] Fung, K., Krewski, D., Burnett, R. and Dominici, F., "Testing the harvesting hypothesis by time-domain regression analysis. I: baseline analysis," Journal of Toxicology and Environmental Health, Part A, vol. 68, pp. 1137-1154, 2005.

[5] Goudarzi, G., Mohammadi, M. J., Angali, K. A., Neisi, A. K., Babaei, A. A., Mohammadi, B., Soleimani, Z. and Geravandi, S., "Estimation of health effects attributed to $\mathrm{NO}_{2}$ exposure using Air QModel," Archives of Hygiene Sciences, pp. 59-66, 2011.

[6] Krzyzanowski, M., "WHO air quality guidelines for Europe," Journal of Toxicology and Environmental Health, Part A, pp. 47-50, 2008.

[7] Miri A., Ahmadi H., Ghanbari A. and Moghaddamnia, A., "Dust storms impacts on air pollution and public health under hot and dry climate," Int. J. Energy Environ, pp. 101-105, 2007.

[8] Barnett, A. G., Williams, G. M., Schwartz, J., Best, T. L., Neller, A. H., Petroeschevsky, A. L. and Simpson, R. W., "The effects of air pollution on hospitalizations for cardiovascular disease in elderly people in Australian and New Zealand cities," Environmental Health Perspectives, pp. 1018-1023, 2006.

[9] Sunyer, J., Basagana, X., Belmonte, J. and Anto, J., "Effect of nitrogen dioxide and ozone on the risk of dying in patients with severe asthma," pp. 687-693, 2002.

[10] Krzyzanowski, M., Cohen, A. and Anderson, R. "Quantification of health effects of exposure to air pollution," Occupational and Environmental Medicine, pp. 791-793, 2002.

[11] KuĖnzli, N., Kaiser, R., Medina, S., Studnicka, M., Chanel, O., Filliger, P., Herry, M., Horak Jr, F., Puybonnieux-Texier, V. and Quenel, P., "Public-health impact of outdoor and traffic-related air pollution: a European assessment," The Lancet, pp. 795-801, 2000.

[12] Badescu, V. and Cathcart, R., "Macro-engineering seawater in unique environments: Arid lowlands and water bodies rehabilitation," Springer, pp. 323-329, 2011.

[13] Ghozikali, M. G., Mosaferi, M., Safari, G. H. and Jaafari, J., "Effect of exposure to $\mathrm{O}_{3}, \mathrm{NO}_{2}$, and $\mathrm{SO} 2$ on chronic obstructive pulmonary disease hospitalizations in Tabriz," Iran. Environmental Science and Pollution Research, pp. 1-7, 2014.

[14] M. Cannistraro, S. G. Leonardi, D. Aloisio, E. Patti, C. Pace, W. Khalaf, N. Donato and G. Neri: "Development of electronic-nose technologies for biomedical applications," XVII Annual Conference AISEM Brescia, Feb. 5-7 2013.

[15] Sistema Nazionale per la Protezione Ambientale, ISPRA, A.N.C.I. "Qualità dell'ambiente Urbano", IX Rapporto 2013, Stato dell'Ambiente 45, 2013.

[16] G. Cannistraro, M. Cannistraro and R. Restivo, "Some observations on the radiative exchanges influence on thermal comfort in rectangular open-space environments," Intern. Journal of Heat \&Technology, vol. 33, no. 2, pp. 79-84, 2015. DOI: 10.18280/ijht.330213.

[17] G. Cannistraro, M. Cannistraro and R. Restivo, "The local media radiant temperature for the calculation of comfort in areas characterized by radiant surfaces," International Journal of Heat \& Technology, vol. 33, pp. 115-122, 2015. DOI: 10.18280/ijht.330116.

[18] M. Cannistraro, G. Cannistraro A. Piccolo and R. Restivo, "Potential and limits of oxidative photocatalyses and possible applications in the field of cultural heritage," Advanced Materials Research, vol. 787, pp. 111-117, 2013, Trans Tech Publications, Switzerland.

[19] G. Cannistraro, M. Cannistraro, A. Cannistraro, A. Galvagno and G. Trovato, "Evaluation of the convenience of a citizen service district heating for residential use. A new scenario introduced by high efficiency energy system," International Journal of Heat \& Technology, vol. 33, no. 4, pp. 167 and 172, 2015. DOI: $10.18280 /$ ijht.330421.

[20] G. Cannistraro, M. Cannistraro and R. Restivo, "Messina's historical buildings after the earthquake of 1908: Energy and environmental analysis through a 
global screening methodology," International Journal of Heat \& Technology, vol.31, no. 2, pp. 155, 158, 2013. DOI: $10.18280 /$ ijht. 310221.

[21] G. Cannistraro and M. Cannistraro, "Hypothermia risk, monitoring and environment control in operating rooms"International Journal of Heat \& Technology, vol. 34 , no. 2, June 2016, pp. 165, 171, 2016. DOI: 10.18280/ijht.340202.

[22] G. Cannistraro, M. Cannistraro and A. Galvagno, "An innovative system for monitoring local pollution in urban areas," Congress WSEAS, Jan 29-31, 2016.

[23] G. Cannistraro, M. Cannistraro, A. Galvagno and G. Trovato, "Reduced of demand of energy cooling in the CED, centers of processing data, with use of freecooling systems," International Journal of Heat \&
Technology, vol. 34 , no. 3 , pp. 408, 502, 2016. DOI: 10.18280/ijht.340321.

[24] G. Cannistraro, M. Cannistraro, A. Galvagno and G. Trovato, "Evaluations technical and economic the integrations of co-trigeneration systems in the dairy industry," International Journal of Heat and Technology, vol. 34, Special Issue 2, October 2016, to be published.

[25] G. Cannistraro, M. Cannistraro and A. Cannistraro: "Evaluation of the sound emissions and climate acoustic in proximity of one railway station," International Journal of Heat and Technology, vol. 34, Special Issue 2, October 2016, DOI: $10.18280 /$ ijht.34S2, to be published. 